\title{
Effects of ammonia nitrogen on gill mitochondria in clam Ruditapes philippinarum
}

\author{
Ming Cong ${ }^{\mathrm{a}}$, Huifeng $\mathrm{Wu}^{\mathrm{a}, \mathrm{b}, *}$, Tengfei Cao ${ }^{\mathrm{a}, \mathrm{c}}$, Chenglong $\mathrm{Ji}^{\mathrm{a}}{ }^{\mathrm{a} b}$, Jiasen $\mathrm{Lv}^{\mathrm{c}}$ \\ ${ }^{a}$ Key Laboratory of Coastal Environmental Processes and Ecological Remediation, Yantai Institute of Coastal Zone Research (YIC), Chinese Academy of Sciences (CAS), \\ Shandong Provincial Key Laboratory of Coastal Environmental Processes, YICCAS, Yantai 264003, PR China \\ ${ }^{\mathrm{b}}$ Laboratory for Marine Fisheries Science and Food Production Processes, Qingdao National Laboratory for Marine Science and Technology, Qingdao 266237, PR China \\ ${ }^{\mathrm{c}}$ Biology School of Yantai University, Yantai 264005, PR China
}

\section{A R T I C L E I N F O}

\section{Keywords:}

Ruditapes philippinarum

Ammonia nitrogen

Mitochondrial transmembrane potential

ATPase

Gill function

Histological observation

\begin{abstract}
A B S T R A C T
Ammonia nitrogen exposure has been found to significantly increase the early apoptosis rates of gill cells, affect the contents of ATP and disturb expressions of calcium-related genes in clam Ruditapes philippinarum. Mitochondria are the centers for energy production, initiation of apoptosis and calcium signal regulation. It is hypothesized that gill mitochondrion is a target organelle for the ammonia nitrogen. Thus, ATP metabolism together with ATP-consuming functions would be interfered by ammonia exposure. In the present study, mitochondrial transmembrane potential (MTP), ATPase activities, gill functions in clearance and respiration, and histological changes were detected to characterize the effects of ammonia to the gill mitochondria in clam $R$. philippinarum. Results indicated that ammonia exposure led to significant decreases in MTP, $\mathrm{Ca}^{2+}$-ATPase activity and clearance rates. However, different concentrations of ammonia nitrogen induced different variations on $\mathrm{H}^{+}, \mathrm{K}^{+}$-ATPase activity and respiration rates. Histological observation revealed that subacute exposure of ammonia damaged the microstructure of gill tissues. Therefore, ammonia exposure dramatically damaged the normal structure and function of mitochondria, resulting in irreversible damage in energy formation and supply. In addition, it affected $\mathrm{Ca}^{2+}$ and $\mathrm{K}^{+}$metabolism and inhibited food intake and respiration in clam R. philippinarum.
\end{abstract}

\section{Introduction}

In the last decades, marine aquaculture in China has developed quickly and the production has been increased four times over 30 years. Of the culturing species, marine molluscs account for the highest proportion $(\sim 78.6 \%)$ of the total aquatic production (Tang et al., 2016). Since marine molluscs especially bivalve intake food by filtering organic particles from the environment (Frankic and Hershner, 2003), bivalve culturing has been regarded as the most potential one in sustainable aquaculture. But intensive bivalve culturing brings some adverse effects to the marine environment. It was reported that about $60 \%$ of the plankton could be filtered by intensively cultured marine bivalve (Jiang et al., 2016). A large portion of the organic particles was transformed into ammonia by the marine bivalves, other benthonic organisms and microorganisms during their feeding, transformation and catabolism (Yuan et al., 2008, 2011). So the bivalve aquaculture produces certain ammonia pollution to marine environment. More seriously, rapid development of human society produces many organic pollutants containing nitrogen from modern industry, agriculture and other anthropogenic activities. According to the environmental quality bulletin of Chinese coastal waters (2017), the average concentration of ammonia nitrogen in estuaries of the target rivers reached $1.1 \mathrm{mg} / \mathrm{L}$, far beyond the limit concentration for aquaculture (GB11607-89, $0.02 \mathrm{mg}$ / L). Ammonia pollution from rivers brings serious stress to the marine animals especially around the river entrance. Therefore, ammonia is an important pollutant that cannot be ignored in intensive culturing environment of marine bivalves around the coastlines of China.

In marine environment, ammonia exists in two different forms as $\mathrm{NH}_{4}{ }^{+}$(ionized form) and $\mathrm{NH}_{3}$ (un-ionized form) (Francis-Floyd et al., 2009). Compared with $\mathrm{NH}_{4}{ }^{+}, \mathrm{NH}_{3}$ (ammonia nitrogen) can easily diffuse cross the cell membrane, and induce detrimental effects. It can seriously cause attenuated immune reactions, disturbed energy allocation, significant variations in important substance metabolism and gene expressions, and even decreased survival rates to the aquatic animals

\footnotetext{
* Corresponding author at: Key Laboratory of Coastal Environmental Processes and Ecological Remediation, Yantai Institute of Coastal Zone Research (YIC), Chinese Academy of Sciences (CAS), Shandong Provincial Key Laboratory of Coastal Environmental Processes, YICCAS, Yantai 264003, PR China.

E-mail address: hfwu@yic.ac.cn (H. Wu).
} 
(Keppler, 2007; Widman et al., 2008; Maas et al., 2012; Wang et al., 2012; Cong et al., 2017, 2018). In vertebrates, ammonia nitrogen was found to mainly induce mitochondrial permeability transition and neurotoxicity by activation of NMDA receptor-NO-cGMP pathway (Oja et al., 2017; Kosenko et al., 1994; Bai et al., 2001). However, toxicological mechanism of ammonia nitrogen to marine invertebrate remains unknown.

The clam Ruditapes philippinarum is one of the most commercially important marine bivalve molluscs and contributes a large part to the shellfish production all over the world. In our previous studies, ammonia nitrogen exposure was found to significantly reduce the integrity of lysosome, increase the early apoptosis rates of gill cells, affect the contents of ATP, and reduce the basal layer and longitudinal muscle after a 3-day of ammonia exposure (Cong et al., 2017). It is well known that mitochondria are the primary sites for ATP production, apoptosis initiation, important ions (calcium and potassium) metabolism regulation (Díaz-Vegas et al., 2018; Wen, 2018). Reduced ATP contents suggested that ammonia nitrogen exposure would probably damage the normal function of gill mitochondria, and inhibit the normal functions of gill tissues. However, it remains unknown that if the membrane system of mitochondria is damaged, whether ATPase activities are influenced by ammonia, how the ingestion and respiration activities of the clams are affected, and to what extent a subacute exposure would damage the gill tissue. Till now, we have little information about these questions.

In the present study, clam $R$. philippinarum was used as the experimental animal to receive an ammonia exposure for 21 days. Mitochondrial transmembrane potential (MTP) of the haemocytes and gill cells, $\mathrm{Ca}^{2+}$-ATPase and $\mathrm{H}^{+}, \mathrm{K}^{+}$-ATPase activities were detected to elucidate the adverse effects of ammonia nitrogen on the mitochondria. Functional detection (clearance and respiration rates) and pathological observation of gill tissues were performed to find the effects of a subacute exposure of ammonia nitrogen on clam gill tissue. This study will help to further investigate the ammonia nitrogen-induced toxic effects and the related mechanism in clams, especially to elucidate the target toxic effects in mitochondria from clam gills.

\section{Materials and methods}

\subsection{Clam cultures, ammonia nitrogen exposure and tissue sampling regimens}

Clams R. philippinarum (full shell length $3.5 \pm 0.3 \mathrm{~cm}$ ) were obtained from a market (Yantai, China) in March 2017. Before the experiment, clams were acclimated in tanks $(60 \mathrm{~cm} \times 60 \mathrm{~cm} \times 30 \mathrm{~cm})$ containing $50 \mathrm{~L}$ of sand-filtered seawater (salinity $31 \%$, $\mathrm{pH}$ 8.0) with aeration at a temperature $17 \pm 1{ }^{\circ} \mathrm{C}$ for 1 week. During the acclimatization and exposure periods, the clams were fed twice a day on a diet of commercial condensed Isochrysis galbana and Chlorella vulgaris Beij (density $\approx 2 \times 10^{10}$ cells $/ g, 3 \%$ of the wet weight of the clams). All the seawater was changed twice just before and $2 \mathrm{~h}$ past the feeding in each tank daily. The whole experiment was maintained under a photoperiod of $12 \mathrm{~h}$ light and $12 \mathrm{~h}$ dark.

Stock solution of $1 \mathrm{~mol} / \mathrm{L} \mathrm{NH}_{4} \mathrm{Cl}$ was used as the total nitrogen source. According to the previous studies, the concentrations of 0.1 and $0.5 \mathrm{mg} / \mathrm{L}$ of ammonia nitrogen could induce obviously adverse effects to the clams, such as reducing the integrity of lysosome, increasing the early apoptosis rates of gill cells, decreasing the contents of ATP, and reducing the basal layer and longitudinal muscle (Cong et al., 2017). Therefore, the concentrations of 0.1 and $0.5 \mathrm{mg} / \mathrm{L}$ of ammonia nitrogen were used as the low and high exposures, respectively. The concentrations of ammonia nitrogen in each exposed group were calculated according to Francis-Floyd et al. (2009). Clams were randomly divided into three groups with three replicates in each group (150 individuals in each replicate). During the ammonia nitrogen exposure treatments for 21 days, the occurrence and numbers of dead clams were recorded daily and the dead ones were immediately removed from the aquaria. After the seawater was completely replaced, $\mathrm{NH}_{4} \mathrm{Cl}$ stock solution was added to the seawater to keep a continuous ammonia nitrogen exposure. Clams from each replicate were sampled randomly at 0-, 1-, 3-, 7-, 14and 21-day time points, respectively.

At each sampling time-point, three parts of gill tissues were collected, respectively. The first part was used to detect the mitochondrial transmembrane potential (MTP). The second part was immediately frozen in liquid nitrogen and used later to measure the ATPase activities. The third part of gill tissue was quickly fixed in Bonn's liquid (saturated picric acid: formaldehyde: glacial acetic acid $=15$ : $5: 1$; v/ v/ v) and used for histological analysis. In addition, MTP of the haemocytes were also detected. Briefly, the hemolymph sample was obtained from the pericardial cavity of the clams by a sterilized syringe and mixed quickly with an equal volume of the anti-coagulant ( $450 \mathrm{mmol} / \mathrm{L} \mathrm{NaCl}, 100 \mathrm{mmol} / \mathrm{L}$ glucose, $30 \mathrm{mmol} / \mathrm{L}$ trisodium citrate, $26 \mathrm{mmol} / \mathrm{L}$ citric acid, $10 \mathrm{mmol} / \mathrm{L}$ EDTA, $\mathrm{pH}$ 7.45) modified from the anti-coagulant by Söderhäll and Smith (1983). After collection, the samples were immediately centrifuged at $800 \mathrm{~g}$ for $5 \mathrm{~min}, 4^{\circ} \mathrm{C}$. The haemocytes at the tube bottom were used in the assay of MTP. For the above analysis, six clams of each group were collected at 0-, 3-, 7-, 14-, 21-day time points, respectively. For the assays of gill functions including clearance rates and respiration rates, fifteen clams were used as a replicate in each group, respectively.

\subsection{Mitochondrial transmembrane potential (MTP) assay}

For the detection of MTP of the gill cells, trypsin was used to get dispersed gill cells. In details, gill tissues were gently cut by sterilized scissors into fragments about $1 \mathrm{~mm}^{3}$ in size, and added with $0.25 \%$ trypsin-EDTA solution (Sigma-Aldrich) to $500 \mu \mathrm{L}$ of total volume. The mixed samples were digested at $20^{\circ} \mathrm{C}$ for $15 \mathrm{~min}$ and stopped by adding $500 \mu \mathrm{L}$ of $15 \%$ fetal bovine serum (Gibco). Then the mixture was centrifuged at $800 \mathrm{~g}$ for $5 \mathrm{~min}$ at $4{ }^{\circ} \mathrm{C}$. The dispersed gill cells and the collected haemocytes were used to detect the membrane potential using JC-1 assay kit (Beyotime Biotechnology), according to the operational manual. The gill cells and haemocytes were incubated with JC-1 for $20 \mathrm{~min}$ at $20^{\circ} \mathrm{C}$. After the cells were collected at $600 \mathrm{~g}$ for $3 \mathrm{~min}$ and washed with JC-1 dye buffer for two times, MTPs of the cells were analyzed by a flow cytometer (BD Biosciences, USA). Carbonyl cyanide 3-chlorophenylhydrazone (CCCP, Sigma-Aldrich) is an uncoupler of oxidative phosphorylation and induces MTP disruption. In the present study, CCCP was added to the haemocytes or gill cells to a final concentration of $10 \mu \mathrm{M}$ and incubated for $20 \mathrm{~min}$. Then the mixture was used as a JC-1 positive control.

\subsection{ATPase activities assay}

$\mathrm{Ca}^{2+}$-ATPase and $\mathrm{H}^{+}, \mathrm{K}^{+}$-ATPase activities in the gills of $R$. philippinarum were measured in the experiment. Briefly, gill tissues were ground in liquid nitrogen, and enzymatic activities of $\mathrm{Ca}^{2+}$-ATPase and $\mathrm{H}^{+}, \mathrm{K}^{+}$-ATPase were assayed by a multiskan spectrum microplate spectrophotometer (Infinite M200, TECAN) according to the manufacturer's protocols (Jiancheng, Nanjing, China). BCA assay kit (Pierce) was used to measure the total protein concentrations in the gill samples to normalize the data of ATPase activities, which were expressed in term of units per mg of protein.

\subsection{Functional evaluation of clam gill tissue}

Two parameters, clearance rates (CRs) and respiration rates (RRs), were used to represent the functional state of clam gill. For the detection of CRs, there were three experimental replicates (with 15 clams in 1-L aquaria for each replicate) in each group. Another three identical aquaria without clams were used as the blank group. After the clams were allowed to acclimate for $10 \mathrm{~min}, 100 \mathrm{~mL}$ of microalgae chlorella 
was added to the aquaria to an initial concentration of $200 \sim 300$ cells per $\mathrm{mL}$. One microliter of microalgae mixture in each experiment aquaria was collected to count the number of microalgae by the aid of cytometer (BD, Accuri ${ }^{\circledast}$ C6 Plus) at $0,15,30$ and 60 min post the acclimation period respectively. $\mathrm{CR}$ was calculated according to the method described by Coughlan and Xu (Coughlan, 1969; Xu et al., 2016): $\mathrm{CR}=\mathrm{V} \times\left(\ln \mathrm{C}_{0}-\ln _{\mathrm{t}}\right) / \mathrm{Nt}$, where $\mathrm{CR}$ is the clearance rate $(\mathrm{L}$ $\mathrm{g}^{-1} \mathrm{~h}^{-1}$ ), $\mathrm{V}$ represents the water volume in the aquaria (L), $\mathrm{C}_{0}$ represents the initial concentration of microalgae (cells $\mathrm{L}^{-1}$ ), $\mathrm{C}_{\mathrm{t}}$ represents the concentration of microalgae at time $t$ (cells $\mathrm{L}^{-1}$ ), $\mathrm{N}$ represents the number of experimental clams in the aquaria, and t represents the time elapsed (h). At the end of CR measurements, total soft tissue of clams were collected and dried at $60^{\circ} \mathrm{C}$ for $24 \mathrm{~h}$. All of the CR values were standardized to unit per dry weight of the clams.

Similarly, there were three replicates (each with 15 clams) for the assay of respiration rates (RRs) in the control, low and high ammonia nitrogen exposed-groups, respectively. RR value was determined for fifteen clams in a closed respirometer chamber (Loligo Systems AR15150, DAQ-PAC-WF4) filled with seawater from the corresponding group for one hour. The RR assay began about $20 \mathrm{~min}$ later when the clams opened their valves in the respirometer chamber. And three champers without clams were used to collect DO concentrations for the blank group. The oxygen concentration in each closed chamber was recorded at the beginning and the end of the RR test. Then the RR was calculated as the following formula according to $\mathrm{Hu}$ and $\mathrm{Zhao} \mathrm{Hu}$ et al., 2017; Zhao et al., 2018): $\left.\mathrm{RR}=\left[\mathrm{C}_{\mathrm{t} 0}-\mathrm{C}_{\mathrm{t} 1}\right)\right] \times \mathrm{V} / \mathrm{Nt}$, where $\mathrm{C}_{\mathrm{t} 0}$ and $\mathrm{C}_{\mathrm{t} 1}$ represent the $\mathrm{DO}$ concentrations at the beginning and end of the RR test ( $\mathrm{mg} \mathrm{O}_{2} \mathrm{~L}^{-1}$ ), respectively. $\mathrm{V}$ represents the volume of the seawater (L), $\mathrm{N}$ represents the number of clams in the respirometer chamber, $t$ represents the time of RR test (h). In addition, the total soft tissue of clams was collected and dried at $60^{\circ} \mathrm{C}$ for $24 \mathrm{~h}$, and all of the $\mathrm{RR}$ values were standardized to unit per dry weight of the clams.

\subsection{Histopathology analysis}

Gill tissues of clams were separated gently by surgical scissors. Then they were operated according to the approaches described previously (Cong et al., 2017). After the gills were fixed, embedded and cut to slices of $6-8 \mu \mathrm{m}$ thickness, they were stained with hematoxylin and eosin (H. E.), and sealed by neutral balsam. These gill sections were observed (at magnification $\times 200$ and $\times 400$ ) and taken photomicrographs using a light microscope (Olympus, Japan).

\subsection{Statistical analysis}

The data were expressed as means \pm standard deviation and subjected to one-way analysis of variance (one-way ANOVA) followed by least significant difference (LSD) analysis by SPSS 19.0 to show the effects of ammonia nitrogen exposures on the clams. The statistical significances were defined at $P<0.05$ for normal significance, $P<$ 0.01 for high significance, and $P<0.001$ for very high significance.

\section{Results}

\subsection{MTP detections of gill cells and haemocytes}

MTPs of the gill cells and haemocytes were examined after ammonia nitrogen exposure. Results were shown in Figs. 1 and 2 . It is known that JC-1 can enter and be accumulated into mitochondria of healthy cells as a dimeric with red fluorescence, and release from collapsed mitochondria to cytoplasm as monomeric form with green light fluorescence. Therefore, the red parts in Fig. 1 represent healthy mitochondria with normal MTPs and the green parts represent damaged mitochondria with dissipated MTPs. A systematical analysis (Fig. 2) revealed that higher MTP dissipation ratios occurred in the haemocytes after the clams were exposed to $0.5 \mathrm{mg} / \mathrm{L}$ ammonia nitrogen for 7 days $(P<$
0.001), 14 days $(P<0.001)$ and 21 days $(P<0.001)$, respectively. And the exposure of $0.1 \mathrm{mg} / \mathrm{L}$ ammonia nitrogen induced significant MTP dissipation in the haemocytes at day $3(P<0.01), 14(P<$ $0.001)$ and $21(P<0.001)$. It indicated that ammonia nitrogen exposure at the experimental concentrations exerted obvious damages to the mitochondria of clam haemocytes, especially after exposure for 14 days.

Compared with the data of haemocytes, 0.1 and $0.5 \mathrm{mg} / \mathrm{L}$ ammonia exposures induced significant MTP dissipations of gill cells at day 1 $(P<0.05, P<0.05), 3(P<0.01, P<0.01), 7(P<0.05$, $P<0.05), 14(P<0.001, P<0.01)$ and $21(P<0.001, P<0.001)$, respectively. It took an obviously shorter period for decreasing the MTP ratios in the gill cells ( 1 day) than that in the haemocytes ( 3 days), which indicated that ammonia exposure caused more rapid MTP dissipation in the gill cells than that in the haemocytes.

\subsection{ATPase activities of gill cells}

In order to investigate the damage of ammonia nitrogen on gill mitochondria, activities of $\mathrm{Ca}^{2+}$-ATPase and $\mathrm{H}^{+}, \mathrm{K}^{+}$-ATPase in the gill cells were assayed. Results (Fig. 3) showed that $0.5 \mathrm{mg} / \mathrm{L}$ of ammonia nitrogen significantly reduced the activities of $\mathrm{Ca}^{2+}$-ATPase at day 1 $(P<0.05), 3(P<0.001), 7(P<0.05), 14(P<0.01)$ and 21 $(P<0.001)$. However, $\mathrm{Ca}^{2+}$-ATPase activities of the $0.1 \mathrm{mg} / \mathrm{L}$ ammonia nitrogen-exposed group exhibited significant decrements at day $3(P<0.01)$ and $14(P<0.01)$.

By comparison, $\mathrm{H}^{+}, \mathrm{K}^{+}$-ATPase showed a different variation profile after ammonia nitrogen exposure. In details, $\mathrm{H}^{+}, \mathrm{K}^{+}$-ATPase activities of 0.1 and $0.5 \mathrm{mg} / \mathrm{L}$ ammonia nitrogen-exposed groups significantly decreased at day $1(P<0.01)$ and $3(P<0.05)$, respectively. After that, the $\mathrm{H}^{+}, \mathrm{K}^{+}$-ATPase activities of the $0.1 \mathrm{mg} / \mathrm{L}$ group slightly increased but exhibited no significance. However, the $\mathrm{H}^{+}, \mathrm{K}^{+}$-ATPase activities of $0.5 \mathrm{mg} / \mathrm{L}$ group remained significant increments at 7$(P<0.001), 14-(P<0.05)$ and 21 -day time points $(P<0.001)$. It indicated that the adverse effects of ammonia nitrogen on $\mathrm{H}^{+}, \mathrm{K}^{+}$. ATPase activity was repairable when the clams were exposed at $0.1 \mathrm{mg}$ / $\mathrm{L}$ of ammonia nitrogen, however, $0.5 \mathrm{mg} / \mathrm{L}$ of ammonia brought continuous stimulation following a transient inhibition to $\mathrm{H}^{+}, \mathrm{K}^{+}$-ATPase activity.

\subsection{Functional evaluation of clam gill tissue}

Short-term exposure (1 day) of ammonia nitrogen didn't induce significant variation of clearance rates (CRs) in either 0.1 or $0.5 \mathrm{mg} / \mathrm{L}$ ammonia nitrogen-exposed group (Fig. 4). However, significant decrements were observed in both exposed groups at day $3(P<0.05, P<$ 0.01), $7(P<0.05, P<0.01), 14(P<0.001, P<0.001)$, and 21 $(P<0.001, P<0.001)$, respectively.

For the respiration rates (RRs) of the gill tissues (Fig. 5), significant increment $(P<0.001)$ was detected in the $0.1 \mathrm{mg} / \mathrm{L}$ ammonia-exposed group at day 1 . After a recovery period at day 3 , RRs in both exposed groups increased significantly $(P<0.001)$ compared with the control group at day 7. However, the RRs decreased significantly in both low $(P<0.001)$ and high $(P<0.01)$ ammonia nitrogen-exposed groups at day 14 . The RRs in $0.1 \mathrm{mg} / \mathrm{L}$ ammonia nitrogen-exposed group remained a significant decrement $(P<0.001)$ at day 21 .

\subsection{Effects of ammonia nitrogen exposure on gill structure}

Histopathology analysis could intuitively reflect the deterioration status of gill structure after ammonia nitrogen exposure. In the control group, many nucleuses of the lateral cells are distributed intensively and stained light blue by H.E. inside the filaments. Thick cilia arranged orderly around the gill filaments (Fig. 6A). Inside each filament, there was a clear blood sinus surrounded by basal layer. And longitudinal muscle could be distinctly discerned at the bottom of the filaments. 
(1) $\mathbf{A}$
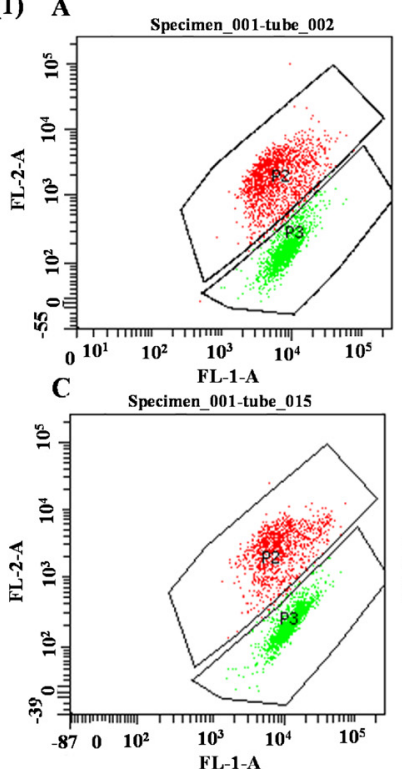

B
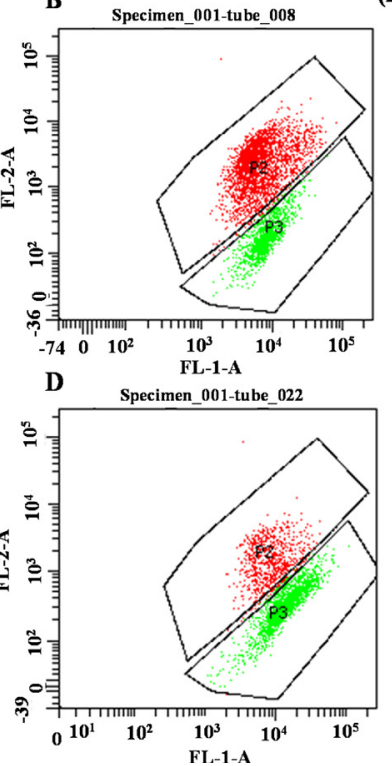

(2) $\mathbf{A}$
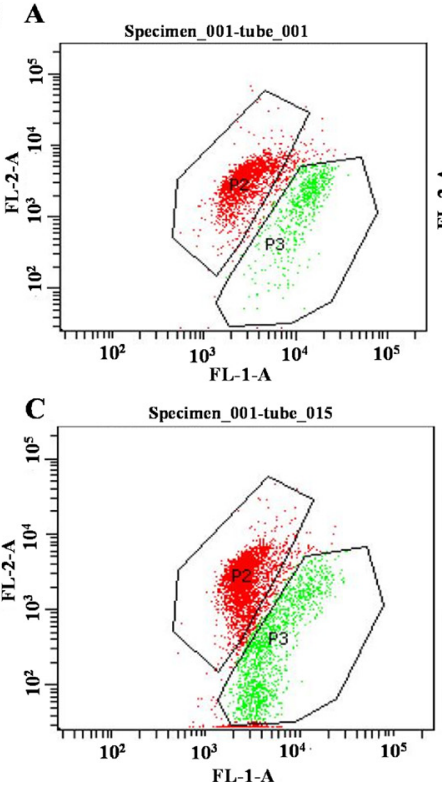

B Specimen_001-tube_007

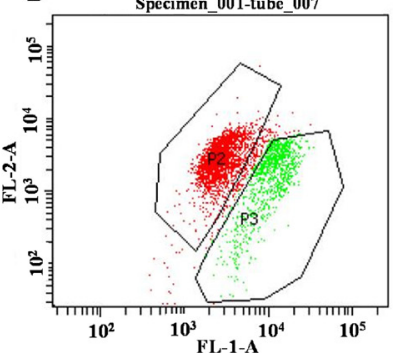

D Specimen_001-tube_022

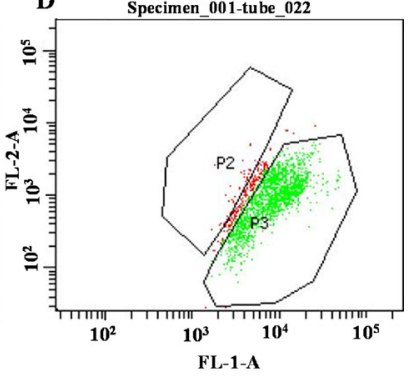

Fig. 1. MTP of clam cells after ammonia nitrogen exposure. (1) Gill cells; (2) Haemocytes.

A. Control group; B. $0.1 \mathrm{mg} / \mathrm{L}$ of ammonia nitrogen exposed group; C. $0.5 \mathrm{mg} / \mathrm{L}$ of ammonia nitrogen exposed group; D. CCCP positive control. P2 represents healthy mitochondria with normal MTPs; P3 represents damaged mitochondria with dissipated MTPs.

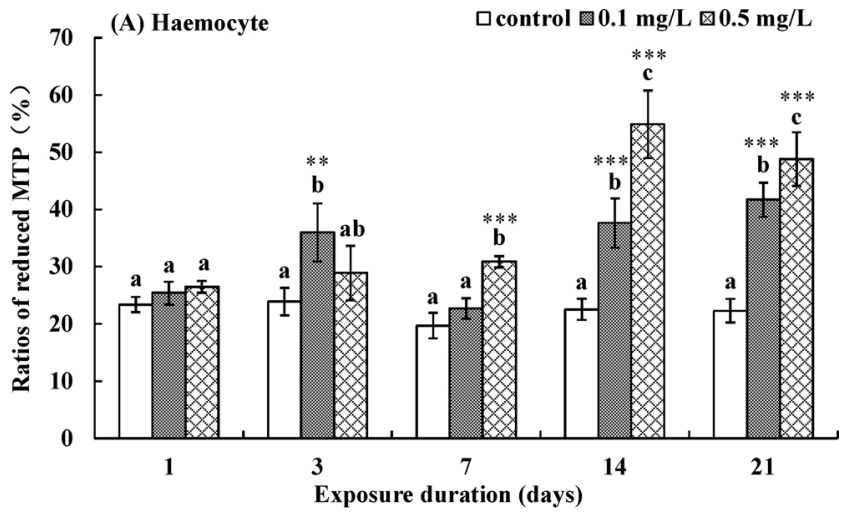

(B) Gill

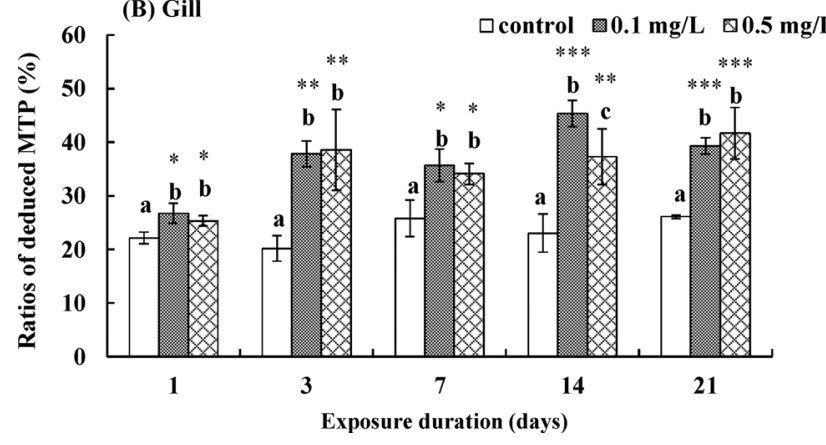

Fig. 2. Ratios of reduced MTP of haemocyte and gill cells.

Different letters above the column denote the differences among the exposed and the control groups. Asterisks denote different significances between each of the exposed group with the control, with one asterisk at $P<0.05$, two asterisks at $P<0.01$ and three asterisks at $P<0.001$.

However, one day exposure of $0.1 \mathrm{mg} / \mathrm{L}$ ammonia nitrogen caused the cilia sparse and nucleus in the lateral cells decreased. Basal layer inside the filament and the muscle element were still discerned (Fig. 6B). And the filaments exhibited anamorphic figure with atrophied basal layers insides in the $0.5 \mathrm{mg} / \mathrm{L}$ ammonia nitrogen-exposed group (Fig. 6D). After a 21-day exposure, the gill cilia became sparse and the basal layer
(A)

$\square$ control $\quad 0.1 \mathrm{mg} / \mathrm{L} \quad \forall 0.5 \mathrm{mg} / \mathrm{L}$

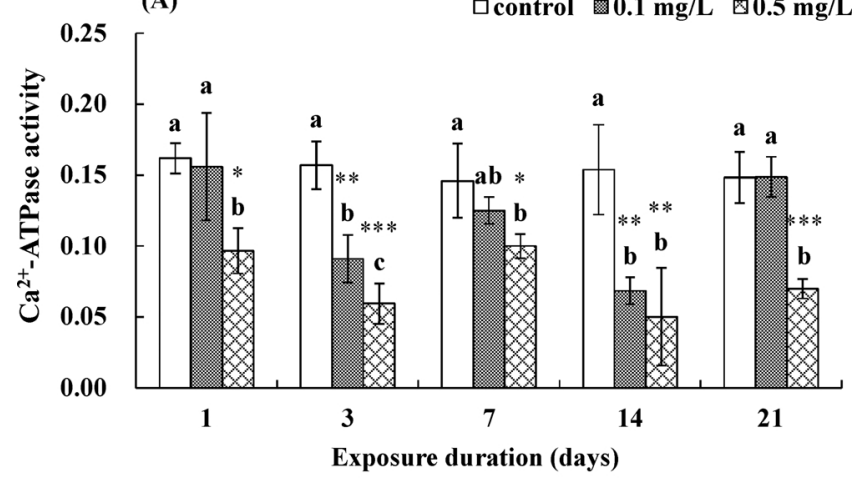

(B)

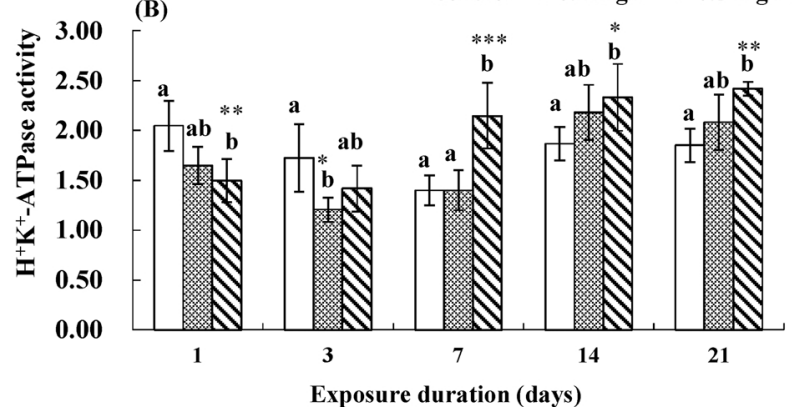

Fig. 3. Activities of $\mathrm{Ca}^{2+}$-ATPase and $\mathrm{H}^{+}, \mathrm{K}^{+}$-ATPase of gill cells after ammonia nitrogen exposure. Note: Different units are used in this figure to denote the values of $\mathrm{Ca}^{2+}$-ATPase and $\mathrm{H}^{+}, \mathrm{K}^{+}$-ATPase, which are expressed as $\mathrm{U} \cdot \mathrm{mg}^{-1}$ prot and $\mathrm{mol} \mathrm{Pi} \cdot \mathrm{mg}^{-1}$ prot $\mathrm{h}^{-1}$, respectively.

was almost diminished in the $0.1 \mathrm{mg} / \mathrm{L}$ ammonia nitrogen-exposed group. Some of the filaments were broken and the muscle elements were reduced heavily (Fig. $6 \mathrm{C}$ ). In the $0.5 \mathrm{mg} / \mathrm{L}$ group, the whole gill tissue was elongated, and the cilia became sparse with some departed from the filaments. The basal layer was seriously damaged and the longitudinal muscle element was reduced to almost disappear. In addition, some heterostructure substances were stained lightly brown around the reduced muscle elements. 


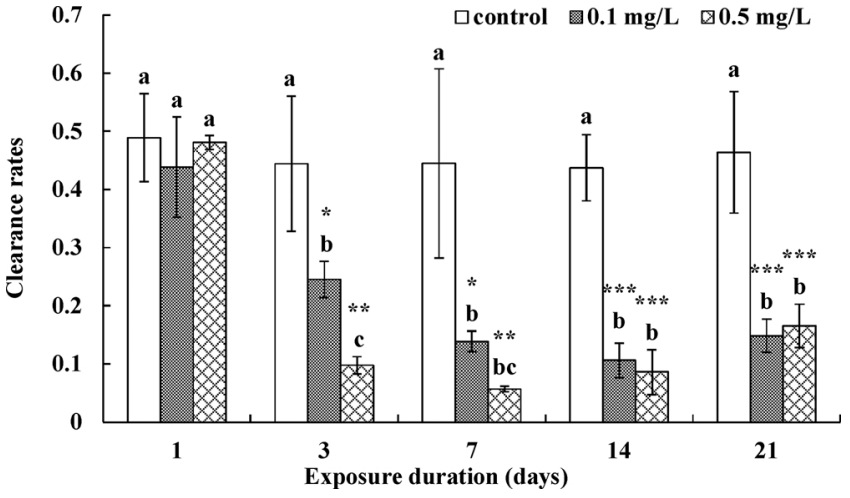

Fig. 4. Variation of clearance rates after ammonia nitrogen exposure. Units are expressed as $\mathrm{L} \cdot \mathrm{g}^{-1} \mathrm{~h}^{-1}$.

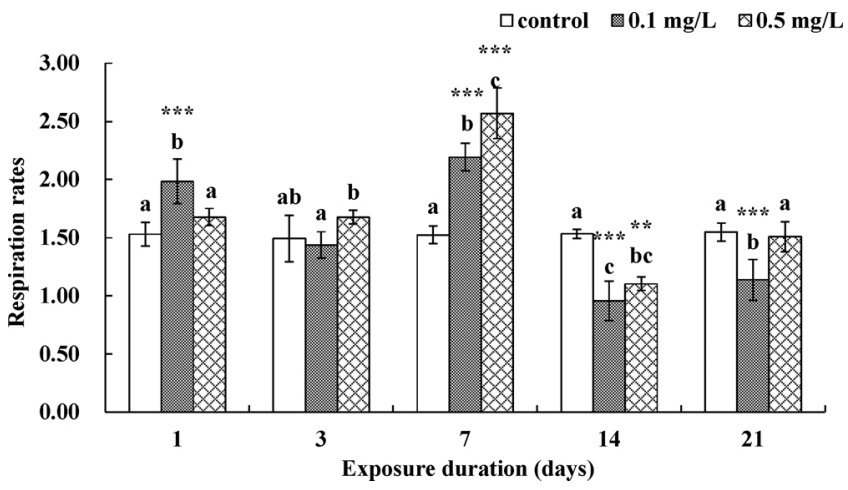

Fig. 5. Variation of respiration rates after ammonia nitrogen exposure. Units are expressed as $\mathrm{mg} \mathrm{O}_{2} \mathrm{~g}^{-1} \mathrm{~h}^{-1}$.

\section{Discussion}

Marine bivalves, such as the clam $R$. philippinarum, are immobile invertebrates and sensitive to environmental pollutants. Ammonia nitrogen is one of the pollutants with raising concerns to bivalve aquaculture. Our previous studies indicated that ammonia exposure affected the clam gill profoundly after exposure for $72 \mathrm{~h}$, including damage to the membrane system (such as lysosome and basal layer), increment in apoptosis rates, decrement in ATP content, and diminished longitudinal muscle in gill (Cong et al., 2017). Since mitochondrion is an important two-membrane organelle playing important roles in ATP production and energy supply, apoptosis initiation, calcium regulation and signal transduction (Alberts et al., 2002), further studies related to the normal functions of mitochondria were conducted presently to well elucidate the underlying mechanism of ammonia nitrogen to the gill tissue of $R$. philippinarum.

In this work, MTP assay revealed that ammonia nitrogen exposure significantly reduce the transmembrane potentials of mitochondria of the clam haemocytes and gill cells. It implied that ammonia exposure damaged the membrane system of mitochondria and led to membrane depolarization. As the results showed, more rapid MTP dissipation ratios were detected in the gill cells compared with those of the haemocytes. Therefore, it can be seen that the gill cells were more vulnerable to ammonia nitrogen exposure and resulted in a more rapid MTP loss than the haemocytes. Since two-membrane is the basis of normal function of mitochondria, loss of MTP suggested that the membrane system of mitochondria was probably damaged by ammonia exposure. In vertebrate, ammonia exposure was found to induce a collapse of the MTP leading to mitochondria dysfunction in the rat astrocytes (Bai et al., 2001). Thus it can be inferred that ammonia exposure would also lead to mitochondrial dysfunction in $R$. philippinarum. And the following measurements of ATPase activities and functions of gill tissue would explain the dysfunction partially.

Two kinds of ATPase activities were measured in this study. $\mathrm{Ca}^{2+}$. ATPase activities were found to be significantly inhibited, especially in the high ammonia exposed-group, which suggested that calcium metabolism was disturbed by ammonia exposure. In our previous study, calcium metabolism-related genes were found to be significantly altered during a 30-day exposure to ammonia characterized by a transcriptomic analysis (Cong et al., 2018), which is consistent with the present result. Since the calcium ion is a critical factor for the initiation and effectuation of cell death controlled by the mitochondria (Orrenius et al., 2015), the significant variation of $\mathrm{Ca}^{2+}$-ATPase might represent the disturbance in calcium regulation of gill mitochondria after ammonia exposure. In another aspect, however, a recent study in C. elegans indicated that inhibition of $\mathrm{Ca}^{2+}$-ATPase could extend the worms' lifespan (García-Casas et al., 2018). Then it can be postulated that the inhibition of $\mathrm{Ca}^{2+}$-ATPase activity might be a protective strategy for the clams to deal with ammonia exposure.

$\mathrm{H}^{+}, \mathrm{K}^{+}$-ATPase is another ATPase detected in the present study. It is an important transporter for both $\mathrm{H}^{+}$and $\mathrm{K}^{+}$in opposite directions by catalyzing ATP to ADP, and specifically activated by $\mathrm{K}^{+}$(Fujii et al., 2015). Garçon et al. (2007) reported that at a certain concentration of $\mathrm{K}^{+}$, increasing $\mathrm{NH}_{4}{ }^{+}$concentrations would stimulate $\mathrm{K}^{+}$-ATPase to its maximum activity and increasing $\mathrm{K}^{+}$couldn't displace $\mathrm{NH}_{4}{ }^{+}$from its exclusive binding sites. Thus the variation profile of $\mathrm{H}^{+}, \mathrm{K}^{+}$-ATPase might reflect the synergistic modulation of $\mathrm{K}^{+}$and $\mathrm{NH}_{4}{ }^{+}$after ammonia exposure. Potassium ion is abundant in cells and plays important roles in mitochondrial physiology, including in membrane potential, matrix volume, generation of reactive oxygen species and so on (Leanza et al., 2015). Under stress, potassium ions will be released and cause cell apoptosis by disrupting mitochondrial potential (Yu et al., 1997; $\mathrm{Yu}, 2003)$. In this study, significant decrement of the $\mathrm{H}^{+}, \mathrm{K}^{+}$-ATPase activities implied that a short period ( $3 \mathrm{~d}$ ) of ammonia exposure inhibited $\mathrm{K}^{+}$release. And the higher concentration $(0.5 \mathrm{mg} / \mathrm{L})$ of ammonia nitrogen caused more rapid (at day 1 ) inhibition of $\mathrm{H}^{+}, \mathrm{K}^{+}$ATPase activity. However, the inhibition was decreased and more $\mathrm{K}^{+}$ would be released from day 7 to day 21 . With the increased $\mathrm{K}^{+}$, according to Garçon et al. (2007), $\mathrm{NH}_{4}{ }^{+}$would compete to activate $\mathrm{H}^{+}$, $\mathrm{K}^{+}$-ATPase and result in disturbance of potassium metabolism with the extension of exposure time.

Homeostasis of $\mathrm{Ca}^{2+}, \mathrm{K}^{+}$ions and normal potential across the two membranes of mitochondria are important for the mitochondria to function effectively in energy production, signal transduction, and so on (Díaz-Vegas et al., 2018; Wen, 2018). A recent study about calcium, potassium and mitochondria membrane depolarization revealed that $\mathrm{K}^{+}$induced membrane depolarization leading to the increment of $\mathrm{Ca}^{2+}$ (Díaz-Vegas et al., 2018). Therefore, it is possible that ammonia nitrogen exposure disturbed ATP metabolisms, such as $\mathrm{Ca}^{2+}$ and $\mathrm{K}^{+}$-related ATPases, which would lead to mitochondria dysfunction in ion metabolism especially during ATP production and cell apoptosis.

Functional evaluation revealed that ammonia exposure significantly affected the normal functions of the clam gill tissue. Clearance rates and respiration rates are two ATP-consuming functions for the clams in nutrient uptake and respiration. In the present study, significant reduction of clearance rates indicated that ammonia exposure heavily impaired the clams' feeding activity. Variation trend of respiration rates implied that ammonia exposure exerted transient hormesis effects followed by significant inhibition for the clams to respire. Hormesis in respiration implied that the clams would be under hypoxia after the ammonia nitrogen exposure. In addition, the transient hormesis in respiration would consume more ATP and result in accelerating ATP depletion, which would in turn affect normal functions of clams, such as $\mathrm{CR}, \mathrm{RR}$ and immunity. Thus the exposure of ammonia would cause the lack of food and oxygen for clams, which would in turn hinder their survival.

Observation of pathological section provided some histological clues related to the decreased clearance rates and respiration rates of $R$. 

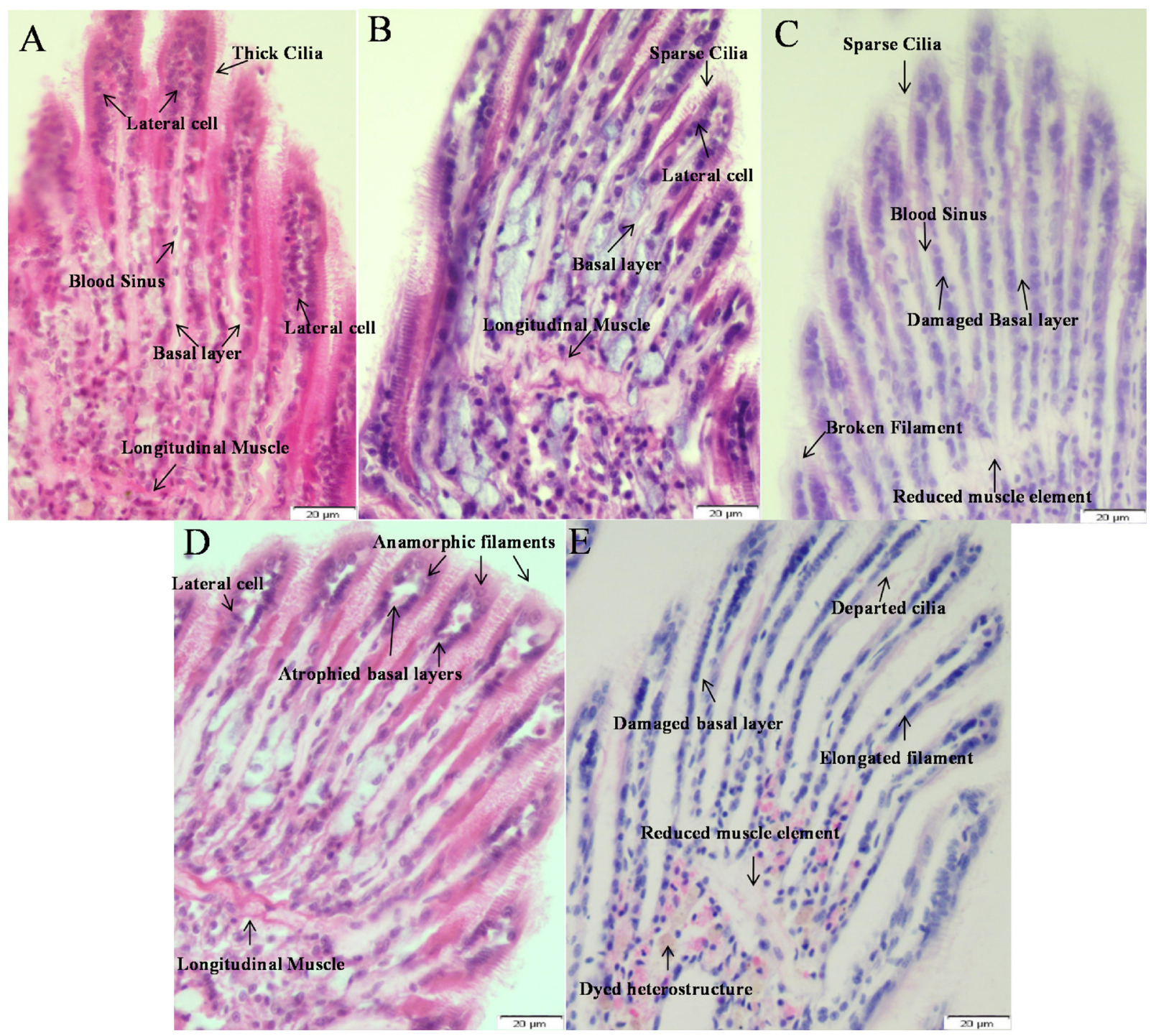

Fig. 6. Paraffin section of $R$. philippinarum gill stained by H.E. after ammonia exposure (Magnification $\times 400$ ).

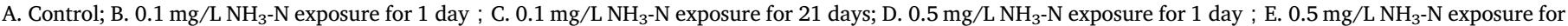
21 days.

philippinarum gill tissues. For a healthy gill tissue, thick cilia around the gill filament can enable the clams to capture and transport suspended particles. The lateral cells in the filament are reported to be responsible for the water pumping through the gill to get food particles and oxygen (Bayne, 2017). In addition, longitudinal muscle is essential for the alteration of gill geometry by narrowing the space between adjacent filaments according to Gainey (2010). It can be figured out that the control clams would alter the geometry shape of gill, efficiently ingest particles and respire freely by the aid of the longitudinal muscle and the dense cilia. However, ammonia nitrogen exposure damaged the microstructure of gill tissue, including sparse cilia, withered basal layer and reduced longitudinal muscle. These defects would hamper the gill tissue to ingest and respire normally, especially after 21-day duration of ammonia exposure.

In conclusion, the present study demonstrated that ammonia nitrogen exposure would reduce the mitochondrial transmembrane potential, inhibit activities of $\mathrm{Ca}^{2+}$-ATPase, induce significant variation of $\mathrm{H}^{+}, \mathrm{K}^{+}$-ATPase, damage the microstructure of gill tissue, and affect the normal functions of gill tissue including feeding and respiration. In combination with increased early apoptosis ratios and decrement in ATP content, it can be seen that ammonia exposure would dramatically damage the normal function and structure of mitochondria, leading to irreversible damage to the clams in energy formation and supply, metal ion metabolism, even survival.

\section{Conflict of interest}

None.

\section{Acknowledgments}

This study was funded by Natural Science Foundation of China (NSFC 41876135), a Key Project from National Key Basic Research Program of China (2015CB453303) and a grant of the Youth Innovation Promotion Association CAS (2015169).

\section{References}

Alberts, B., Johnson, A., Lewis, J., Raff, M., Roberts, K., Walter, P., 2002. The mitochondrion. Molecular Biology of the Cell, 4th ed. Garland Science., New York.

Bai, G., Rama Rao, K.V., Murthy, Ch.R.K., Panickar, K.S., Jayakumar, A.R., Norenberg, M.D., 2001. Ammonia induces the mitochondrial permeability transition in primary cultures of rat astrocytes. J. Neurosci. Res. 66, 981-991.

Bayne, B.L., 2017. Chapter 5. Feeding. Book Chapter in Developments in Aquaculture and Fisheries Science 41. pp. 209-329. 
Cong, M., Wu, H., Yang, H., Zhao, J., Lv, J., 2017. Gill damage and neurotoxicity of ammonia nitrogen on the clam Ruditapes philippinarum. Ecotoxicology 26, 459-469.

Cong, M., Wu, H., Cao, T., Lv, J., Wang, Q., Ji, C., et al., 2018. Digital gene expression analysis in the gills of Ruditapes philippinarum exposed to short- and long-term exposures of ammonia nitrogen. Aquat. Toxicol. 194, 121-131.

Coughlan, J., 1969. The estimation of filtering rate from the clearance of suspensions. Mar. Biol. 2, 356-358.

Díaz-Vegas, A.R., Cordova, A., Valladares, D., Llanos, P., Hidalgo, C., Gherardi, G., et al., 2018. Mitochondrial calcium increase induced by RyR1 and IP3R channel activation after membrane depolarization regulates skeletal muscle metabolism. Front. Physiol. 9, 791.

Francis-Floyd, R., Watson, C., Petty, D., Pouder, D.B., 2009. Ammonia in Aquatic Systems. UF/IFAS University of Florida (UF)/Institute of Food and Agricultural Sciences (IFAS), pp. 5 FA-16.

Frankic, A., Hershner, C., 2003. Sustainable aquaculture: developing the promise of aquaculture. Aquat. Int. 11, 517-530.

Fujii, T., Takahashi, Y., Takeshima, H., Saitoh, C., Shimizu, T., Takeguchi, N., Sakai, H., 2015. Inhibition of gastric $\mathrm{H}^{+}, \mathrm{K}^{+}$-ATPase by 4-(2-butyl-6,7-dichloro-2-cyclopentylindan-1-on-5-yl) oxybutyric acid (DCPIB), an inhibitor of volume-regulated anion channel. Eur. J. Pharmacol. 765, 34-41.

Gainey, L., 2010. Seasonal potentiation of gill muscle contraction in four species of bivalve molluscs. J. Exp. Mar. Biol. Ecol. 391, 43-49.

García-Casas, P., Arias-del-Val, J., Alvarez-Illera, P., Fonteriz, R.I., Montero, M., Alvarez, J., 2018. Inhibition of Sarco-endoplasmic reticulum $\mathrm{Ca}^{2+}$-ATPase extends the lifespan in C. elegans worms. Front. Pharmacol. 9, 669.

Garçon, D.P., Masui, D.C., Mantelatto, F.L.M., McNamara, J.C., Furriel, R.P.M., Leone, F.A., 2007. $\mathrm{K}^{+}$and $\mathrm{NH}_{4}{ }^{+}$modulate gill $\left(\mathrm{Na}^{+}, \mathrm{K}^{+}\right)$-ATPase activity in the blue crab, Callinectes ornatus: fine tuning of ammonia excretion. Comp. Biochem. Physiol. A Mol. Integr. Physiol. 147, 145-155.

Hu, M., Lin, D., Shang, Y., Hu, Y., Lu, W., Huang, X., et al., 2017. CO duction increases physiological toxicity of nano- $\mathrm{TiO}_{2}$ in the mussel Mytilus coruscus. Sci. Rep. 7, 40015.

Jiang, T., Chen, F., Yu, Z., Lu, L., Wang, Z., 2016. Size-dependent depletion and community disturbance of phytoplankton under intensive oyster mariculture based on HPLC pigment analysis in Daya Bay, South China Sea. Environ. Pollut. 219, 804-814.

Keppler, C.J., 2007. Effects of ammonia on cellular biomarker responses in oysters (Crassostrea virginica). Bull. Environ. Contam. Toxicol. 78, 63-66.

Kosenko, E., Kaminsky, Y., Grau, E., Miñana, M.D., Marcaida, G., Grisolía, S., Felipo, V., 1994. Brain ATP depletion induced by acute ammonia intoxication in rats is mediated by activation of the NMDA receptor and $\mathrm{Na}^{+}, \mathrm{K}^{+}$-ATPase. J. Neurochem. 63, $2172-2178$.
Leanza, L., Venturini, E., Kadow, S., Carpinteiro, A., Gulbins, E., Becker, K.A., 2015 Targeting a mitochondrial potassium channel to fight cancer. Cell Calcium 58, 131-138.

Maas, A., Seibel, B.A., Walsh, P.J., 2012. Effects of elevated ammonia concentrations on survival, metabolic rates, and glutamine synthetase activity in the Antarctic pteropod mollusk Clione limacina Antarctica. Polar Biol. 35, 1123-1128.

Oja, S.S., Saransaari, P., Korpi, E.R., 2017. Neurotoxicity of ammonia. Neurochem. Res. 42, 713-720.

Orrenius, S., Gogvadze, V., Zhivotovsky, B., 2015. Calcium and mitochondria in the regulation of cell death. Biochem. Bioph. Res. Co. 460, 72-81.

Söderhäll, K., Smith, V.J., 1983. Separation of the haemo-cyte populations of Carcinus maenas and other marine deca-pods, and prophenoloxidase distribution. Dev. Comp. Immunol. 7, 229-239.

Tang, Q., Han, D., Mao, Y., Zhang, W., Shan, X., 2016. Species composition, non-fed rate and trophic level of Chinese aquaculture. J. Fish Sci.-China 23, 729-758.

Wang, X., Wang, L., Yao, C., Qiu, L., Zhang, H., Zhou, Z., Song, L., 2012. Alternation of immune parameters and cellular energy allocation of Chlamys farreri under ammoniaN exposure and Vibrio anguillarum challenge. Fish Shellfish Immunol. 32, 741-749.

Wen, Y., 2018. Maxwell's demon at work: mitochondria, the organelles that convert information into energy? Chronic Dis. Transl. Med. 4, 135-138.

Widman, J., Meseck, S., Sennefelder, G., Veilleux, D., 2008. Toxicity of un-ionized ammonia, nitrite, and nitrate to juvenile bay scallops, Argopecten irradians. Arch. Environ. Contam. Toxicol. 54, 460-465.

Xu, X., Yang, F., Zhao, L., Yan, X., 2016. Seawater acidification affects the physiological energetics and spawning capacity of the Manila clam Ruditapes philippinarum during gonadal maturation. Comp. Biochem. Physiol. A Mol. Integr. Physiol. 196, 20-29.

Yu, S.P., 2003. Regulation and critical role of potassium homeostasis in apoptosis. Prog. Neurobiol. 70, 363-386.

Yu, S.P., Yeh, C.H., Sensi, S.L., Gwag, B.J., Canzoniero, L.M.T., Farhangrazi, Z.S., et al., 1997. Mediation of neuronal apoptosis by enhancement of outward potassium current. Science 278, 114-117.

Yuan, X.T., Yang, H.S., Zhou, Y., Mao, Y.Z., Xu, Q., Wang, L.L., 2008. Bioremediation potential of sea cucumber Apostichopus japonicas (Selenka) in coastal suspension bivalve aquaculture system. Chin. J. Appl. Ecol. 19, 866-872.

Yuan, X.T., Zhang, S.L., Liu, S.X., Liang, B., Liang, B., Zhang, G.F., 2011. Self-pollution in Ruditapes philippinarum bottom-cultured area of Zhuanghe coast. Chin. J. Appl. Ecol. 22, 785-792.

Zhao, L., Yang, F., Milano, S., Han, T., Walliser, E.O., Schöne, B.R., 2018. Transgenerational acclimation to seawater acidification in the Manila clam Ruditapes philippinarum: preferential uptake of metabolic carbon. Sci. Total Environ. 627, 95-103. 